\title{
The relationship between Arabian Sea upwelling and Indian monsoon revisited
}

\section{Yi, B. Hünicke, N. Tim, and E. Zorita}

Helmholtz-Zentrum Geesthacht, Institute of Coastal Research, Max-Planck-Str.1, 21502 Geesthacht, Germany

Received: 10 September 2015 - Accepted: 20 October 2015 - Published: 6 November 2015 Correspondence to: X. Yi (xing.yi@hzg.de)

Published by Copernicus Publications on behalf of the European Geosciences Union.

The relationship between Arabian Sea upwelling and Indian monsoon revisited

X. Yi et al.

Title Page

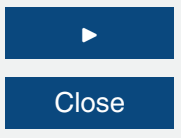

Full Screen / Esc

Printer-friendly Version

Interactive Discussion 


\section{Abstract}

Studies based on upwelling indices (sediment records, sea-surface temperature and wind) suggest that upwelling along the western coast of Arabian Sea is strongly affected by the Indian summer monsoon (ISM). In order to examine this relationship di5 rectly, we employ the vertical water mass transport produced by the eddy-resolving global ocean simulation STORM driven by meteorological reanalysis over the last 61 years. With its very high spatial resolution $(10 \mathrm{~km})$, STORM allows us to identify characteristics of the upwelling system. We analyze the co-variability between upwelling and meteorological and oceanic variables from 1950 to 2010 . The analyses reveal high interannual correlations between coastal upwelling and along-shore windstress $(r=0.73)$ as well as with sea-surface temperature $(r=-0.83)$. However, the correlation between the upwelling and the ISM is small and other factors might contribute to the upwelling variability. In addition, no long-term trend is detected in our modeled upwelling time series.

\section{Introduction}

Coastal upwelling is important as the upwelled nutrient-rich water supports coastal fisheries. It is hypothesized that coastal upwelling will strengthen in the major upwelling regions under the influence of global warming (Bakun, 1990). In support of this hypothesis, Narayan et al. (2010) detected positive trends in upwelling intensity in the four major eastern boundary upwelling systems (EBUSs) and more recently Wang et al. (2015) projects the intensification of upwelling in three of the four EBUSs under a strong increase of anthropogenic greenhouse gas emissions. Beside the EBUSs, the Arabian Sea also has attracted numerous scientific studies due to its connection to the Asian Monsoon. The wind related to the Indian monsoon reverses its direction semiannually. During summer, the southwest monsoon causes upwelling favorable wind that induces upwelling along the west coast of the Arabian Sea (Findlater, 1969). The Ara-
OSD

12, 2683-2704, 2015

The relationship between Arabian Sea upwelling and Indian monsoon revisited

X. Yi et al.

\section{Title Page}

Abstract Introduction

Conclusions References

Tables Figures

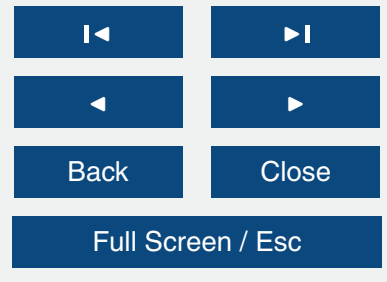

Printer-friendly Version

Interactive Discussion 
bian Sea upwelling and its relationship with the Indian summer monsoon (ISM) have been broadly investigated. Studies based on the abundance of the foraminifera G. bulloides from the sediment records intimately connect the Arabian Sea upwelling and the ISM (Anderson et al., 2002; Curry et al., 1992; Kroon et al., 1991; Prell and Vancampo, 5 1986). More recently, Godad et al. (2011) reconstructed the sea-surface temperature (SST) from planktonic foraminifera and suggested that the peak upwelling season was shifting over the last $22 \mathrm{ka}$ in the western Arabian Sea. A comparison between the foraminifera measured from sediment traps in the western and the eastern Arabian Sea showed that the measurements were significantly correlated to the monsoon but 10 not to the SST and $\mathrm{CO}_{2}$ (Naik et al., 2013). SST is suggested to be the most reliable indicator of the coastal upwelling in the Arabian Sea (Prell and Curry, 1981) and it is applied as a traditional upwelling index by various studies. Emeis et al. (1995) used SST reconstructed from sediment records and Manghnani et al. (1998) processed SST from remote sensing data, while Izumo et al. (2008) combined modeled, in situ and satellite 15 SST data, to derive an upwelling index. In addition, other previous studies have used along-shore upwelling favorable wind-stress as another traditional upwelling index, as originally described by Bakun (1973).

These upwelling indices have been profusely used but they are not a direct measure of upwelling velocities. It is difficult to monitor vertical velocities over a long time span and therefore other studies have resorted to ocean simulations to study the variability of upwelling analyzing directly the vertical velocity. Recently, Jacox et al. (2014) analyzed the vertical velocity from a four-dimensional regional ocean model to investigate the upwelling in the California current system. In the Arabian Sea, Shi et al. (2000) estimated the upwelling velocity off Oman from 1993 to 1995 through the combination of hydrographic and altimetry data. Anderson et al. (1992) employed a simple one-dimensional model to calculate the vertical upwelling velocity off Oman. Rao et al. (2008) used a three-dimensional model to compute the vertical velocity along the west coast of India. Studies applying ocean general circulation models also gave hints on the interaction of upwelling and SST (Ma et al., 2014) and the impact of Kelvin waves at the
OSD

12, 2683-2704, 2015

The relationship between Arabian Sea upwelling and Indian monsoon revisited

X. Yi et al.

Title Page

Abstract Introduction

Conclusions References

Tables Figures

14 I

4

Back

Full Screen / Esc

Printer-friendly Version

Interactive Discussion 
eastern boundary on the western Arabian Sea upwelling region (Tozuka et al., 2014). However, a study focused on the western Arabian Sea based on long-term four dimensional upwelling data is not yet available. In this study we fill this gap by employing the direct upwelling velocity data modeled from a high-resolution global ocean simula5 tion over the period 1950 to 2010 . We compare the upwelling velocity with traditional upwelling indices (SST and wind-stress) and examine the relationship between the upwelling and the ISM as well as other potential factors that might affect the upwelling. An unexpected finding is that the correlations between the simulated upwelling and three different Monsoon indices are low and insignificant, which indicates that over the 10 past 61 years the impact of the ISM on the coastal upwelling in the western Arabian Sea could have been weaker than thought previously and that other large-scale atmospheric forcing is a more efficient drive of upwelling in this region.

\section{Model and data}

The German consortium project STORM aimed at developing high-resolution global cli15 mate change simulations. The ocean model simulation used in this study is hereinafter referred to as the STORM simulation, is based on the Max-Planck Institute Ocean Model (MPI-OM). It is forced by the 6 hourly National Centers for Environmental Prediction (NCEP)/National Center for Atmospheric Research (NCAR) reanalysis (Kalnay et al., 1996) for the period from 1948 to 2010 . The model original bipolar grid is replaced by a tripolar grid to obtain an isotropic horizontal resolution. Comprising $3602 \times 2394$ horizontal grid points in total, the STORM simulation has a horizontal resolution of $0.1^{\circ}$ around the equator and higher towards the poles. The model has 80 levels, separated in the first $200 \mathrm{~m}$ by 10 to $15 \mathrm{~m}$ (von Storch et al., 2012).

Upwelling velocity is derived from the vertical water mass transport in the STORM 25 simulation output. The high spatial resolution of the STORM simulation contributes to capture the upwelling variability on small scales. We compare the upwelling velocity derived from the STORM simulation with SST and wind-stress derived from different
OSD

$12,2683-2704,2015$

The relationship between Arabian Sea upwelling and Indian monsoon revisited

X. Yi et al.

Title Page

Abstract Introduction

Conclusions References

Tables Figures

14

4

Back

Printer-friendly Version

Interactive Discussion 
sources. SST data are obtained from the Advanced Very High Resolution Radiometer (AVHRR) Pathfinder Version 5.0 (Casey et al., 2010). Wind data are provided by the NCEP/NCAR reanalysis and the Cross-Calibrated Multi-Platform (CCMP) project (Atlas et al., 2011). The along-shore upwelling favorable wind-stress is calculated as:

${ }_{5} \quad \tau_{\mathrm{SW}}=\rho \times C_{\mathrm{D}} \times \sqrt{u^{2}+v^{2}} \times(u / \cos \alpha+v / \cos \beta)$

where $\rho$ is the air density which is assumed as $1.22 \mathrm{~kg} \mathrm{~m}^{-3}$ and the drag coefficient $C_{\mathrm{D}}$ is computed using the formulation of Yelland and Taylor (1996); $u$ and $v$ are the zonal (eastward) and meridional (northward) wind speed components respectively; $\alpha$ and $\beta$ are the angles between the along-shore direction and the wind speed components 10 and in this case both of them are assumed to $45^{\circ}$ because in our study the upwelling favorable wind-stress is from the direction of southwest (SW).

In order to estimate the relationship between upwelling and the monsoon, we employ the Indian monsoon index (IMI) defined by Wang and Fan (1999) and the all India monsoon rainfall index (IMR) from the Indian Institute of Tropical Meteorology 15 (Parthasarathy et al., 1994) as well as the Webster and Yang monsoon index (WYM) defined by Webster and Yang (1992). We calculate the IMI and WYM based on wind speed from NCEP/NCAR reanalysis while the IMR is obtained from station rainfall records in India. Besides, several other meteorological and oceanic variables are also investigated. Air temperature data produced by University of Delaware (Willmott and 20 Matsuura, 2012) and sea level pressure (SLP) data from the NCEP/NCAR reanalysis are investigated to provide further understanding. Because of a continuity issue in the STORM simulation output (missing data in 1949), we limit the study period from 1950 to 2010. All data share the same temporal coverage except the period covered by SST data from AVHRR from 1985 to 2009, the wind from CCMP covers from 1988 to 2010, 25
OSD

12, 2683-2704, 2015

The relationship between Arabian Sea upwelling and Indian monsoon revisited

X. Yi et al.

Title Page

Abstract Introduction

Conclusions References

Tables Figures

14 4

Back

Full Screen / Esc

Printer-friendly Version

Interactive Discussion 


\section{Coastal upwelling in the western Arabian Sea}

Upwelling along the west coast of the Arabian Sea usually starts in May and ends in September (Brock et al., 1991). This is well reproduced in the modeled annual cycle of the upwelling velocity (Fig. 1a), which is converted from the original model output of up-

5 ward water mass transport. Thus, positive values indicate upwelling whereas negative values indicate downwelling. The upwelling velocity annual cycle shows that the significant positive values start from May, peak in July and end in September. As one of the traditional upwelling indices, the SW wind-stress (Fig. 1b) is in good consistency with the upwelling velocity with a peak in July as well. Another traditional upwelling index is the observed coastal SST and our modeled SST (Fig. 1c) also reveals good correlation with the upwelling velocity with a lag of approximately one month. This lag can be explained by the time needed to transport deeper and cooler water to the surface and it matches a similar lag between wind-stress and SST found in the observations by Rixen et al. (2000). It is obvious that the ranges of these three annual cycles tend 15 to get larger when the upwelling becomes stronger. Therefore, unless indicated otherwise, we average the values from June to August (JJA) for upwelling velocity and SW wind-stress in the following analyses and we select July to September (JAS) for SST due to the mentioned lag.

The coastal upwelling domain in this study (Fig. 1d) is chosen from 15.2 to $22.3^{\circ} \mathrm{N}$ along the coast of Yemen and Oman with an expansion of $\sim 90 \mathrm{~km}$ (Rixen et al., 2000). According to Brock and Mcclain (1992), we average the upwelling velocity over the upper $200 \mathrm{~m}$ of water. This selected coastal band is very narrow but with the advantage from the high resolution of the STORM simulation we are able to observe the spatial patterns of the upwelling in the study domain. The simulated mean upwelling velocity 25 averaged over this domain in JJA from 1950 to 2010 is about $1.8 \mathrm{~m} \mathrm{day}^{-1}$. Upwelling is less intense in the area north to Ras Madrakah and much stronger at regions near the capes such as Sawqirah and Nishtun where the velocity can exceed $6 \mathrm{mday}^{-1}$.
OSD

12, 2683-2704, 2015

The relationship between Arabian Sea upwelling and Indian monsoon revisited

X. Yi et al.

Title Page

Abstract Introduction

Conclusions References

Tables Figures

14 4 Back

Printer-friendly Version

Interactive Discussion 


\section{Upwelling variability}

For an understanding about the spatial variability of upwelling in this region, we calculate the standard deviation (SD) and perform an Empirical Orthogonal Function (EOF) analysis (von Storch and Zwiers, 2001) of the upwelling velocity. The SD map (Fig. 2a) 5 shows that higher intensity of upwelling comes with higher variance, that is, in the regions where the upwelling velocity is higher (Fig. 1d), the SD of the upwelling velocity is also higher The mean SD over the entire study area is about $0.7 \mathrm{mday}^{-1}$, which is nearly half of the mean upwelling velocity. The EOF analysis is a method that identifies the main spatial patterns of coherent variation. This method identifies spatial patterns, uncorrelated, in time, that describe most of the data variance. The first EOF mode explains most of the variance, which represents the most apparent variation in the data. In our case the leading mode arising from the EOF analysis (Fig. 2b) reveals apparent coastal-offshore pattern and accounts for $10 \%$ of the total variance. The first principal component (PC1) time series is highly consistent with the spatially averaged upwelling velocity $(r=0.82$, shown in Fig. 3b). However, the high SD with respect to the mean value of upwelling velocity and the low explained variance from the first mode of the EOF analysis together indicate that the upwelling in this region is affected by various and complex processes.

Beside the spatial variability, the temporal variability of upwelling is studied as well. 20 The primary attempt is to detect a trend in the upwelling time series referring to the Bakun hypothesis (Bakun, 1990) that upwelling intensification appears at global scale. However, only a negligible increasing trend is revealed over the last 61 years (Fig. 3a). This trend has a slope of $0.0035 \mathrm{~m} \mathrm{day}^{-1}$ year $^{-1}$, which is only $0.2 \%$ of the mean coastal upwelling velocity in the domain. Hence, it is concluded that no detectable trend can be found in our upwelling velocity and thus we do not further discuss about trends in the following text. To make sure all the variables are comparable with each other, we remove the trends in all of them for further analyses.
OSD

12, 2683-2704, 2015

The relationship between Arabian Sea upwelling and Indian monsoon revisited

X. Yi et al.

Title Page

Abstract Introduction

Conclusions References

Tables Figures

14 4 Back

Printer-friendly Version

Interactive Discussion 
We compare the time series of the upwelling velocity with SST and the SW windstress to validate our modeled upwelling data since they are generally applied as coastal upwelling indices (Fig. 3b-d). The time series of upwelling and SST are generated using data within the upwelling domain shown in Fig. 1d while the SW wind-stress 5 time series contains data from a broader area due to the low resolution of the wind data. In Fig. 3b, the upwelling velocity and the PC1 time series from the EOF analysis are compared with SST from the STORM simulation and the SW wind-stress from the NCEP/NCAR reanalysis. The comparison reveals that the upwelling is strongly negatively correlated to the SST $(r=-0.83)$ as well as positively to the SW wind-stresS $10 \quad(r=0.73)$.

Since the SST and the upwelling velocity are both outputs from the STORM simulation and the NCEP wind data is the forcing used in this simulation, these high correlations are to some extent expected and less persuasive without the support from extra sources. Therefore, we employ wind data from CCMP and SST data from AVHRR 15 (Fig. 3c and d) as they are independent of the STORM simulation, although their temporal coverages are shorter than STORM. The correlations between simulated upwelling and these two observed variables are lower (wind $r=0.49$ and SST $r=-0.45$ ) but they remain significant at the $95 \%$ level or higher as in the previous analysis. These results suggest that the upwelling velocity derived from the STORM simulation is significantly consistent with the traditional upwelling indices so it is reasonable to use it for further studies such as investigating the responsible processes affecting the upwelling.

\section{Link to the Monsoon}

As the ISM has been suggested to be strongly linked to the western Arabian Sea upwelling, we examine the relationship between the simulated upwelling velocity and the monsoon indices Indian monsoon index (IMI), all India monsoon rainfall index (IMR) and the Webster and Yang monsoon index (WYM) in Fig. 4. Note that the IMR is computed by integrating the total rainfall records of numerous stations from June to
OSD

12, 2683-2704, 2015

The relationship between Arabian Sea upwelling and Indian monsoon revisited

X. Yi et al.

Title Page

Abstract Introduction

Conclusions References

Tables Figures

14 4

Back

Printer-friendly Version

Interactive Discussion 
September (JJAS) and the data source is not available for single months. Thus, we calculate the IMI and the WYM and also the upwelling velocity for the extended JJAS season. All of the three comparisons show low and negative correlations in the northern part of the domain. Higher correlations are found along the coast and to the south 5 especially the regions with more intense upwelling and larger variance, but only a few areas show correlations that pass the significance level of $95 \%$.

One interesting finding is that the correlation patterns obtained with IMI (Fig. 4a) and with IMR (Fig. 4b) are quite similar. The correlations start to become positive at Ras Madrakah and the highest and the most significant correlations are located between 10 Sawqirah and Nishtun. Besides, the areas with stronger correlation and higher significance highly overlap. Considering the fact that IMI is calculated from the difference of two SLP fields whereas IMR is obtained from the rainfall records, this similarity indicates that the upwelling has very similar link to the variation of the SLP and the rainfall. However, the WYM correlation pattern (Fig. 4c) shows a different case where the pos15 itive values begin to appear from the north of Ras Madrakah and the strongest and most significant correlation lies between Ras Madrakah and Nishtun. Although WYM is also calculated from the difference of two SLP fields, the strategies for selecting the SLP fields are not the same and this is causing the difference between the patterns of IMI and WYM. Additionally, as the SLP-based indices, IMI and WYM patterns capture reduced correlations near Salalah but IMR does not.

The spatially heterogeneous correlations indicate that the upwelling velocities in different regions along the western Arabian Sea coast are sensitive to different forcing mechanisms. Furthermore, it is surprising that the overall correlations of upwelling with all monsoon indices are rather low and insignificant. This analysis, therefore, indicates that the impact of the ISM on western Arabian Sea coastal upwelling is weak and limited to areas with upwelling of higher intensity (Fig. 1d) and variability (Fig. 2a).
OSD

12, 2683-2704, 2015

The relationship between Arabian Sea upwelling and Indian monsoon revisited

X. Yi et al.

Title Page

Abstract Introduction

Conclusions References

Tables Figures

14

4

Back

Full Screen / Esc

Printer-friendly Version

Interactive Discussion 


\section{SLP and Monsoon}

In order to determine the other possible forcings that could influence the variability of upwelling, we correlate the PC1 time series of upwelling to SLP and air temperature in the broader Asian (Indian Ocean) region. As the first principal component time se5 ries from the EOF analysis, PC1 captures the major variation of the upwelling velocity. In Fig. 5a, the correlation between PC1 and SLP is shown in the background contour, while the two-dimensional correlation with wind is superimposed on it. Positive correlation to SLP is found in the Arabian Sea and negative correlation over the Himalayas. The areas with the strongest positive and negative correlations are within the regions used for calculating the IMI. We take one box from the highest positive correlation area and one box from the highest negative correlation area. The SLP gradient between these two areas boxes presents a strong correlation with averaged upwelling PC1 $(r=0.68)$. This is also evidenced in the correlation between the upwelling PC1 and the wind speed vectors. It is obvious that the upwelling PC1 is significantly corre15 lated to the southwestern wind in the Arabian Sea as a result of the gradient of SLP. Furthermore, along the western coast where the upwelling exists, the connection with the southwestern wind is the strongest.

Also importantly, Fig. 5b reveals a link between the upwelling PC1 and the surface air temperature. The upwelling PC1 is positively correlated to the air temperature over the 20 Tibetan Plateau and negatively correlated to that over northern India. Both correlations are significant and similar to the study with the SLP field we select two boxes from the air temperature field as well. The correlation between the upwelling PC1 and the gradient of these two regions is also not negligible $(r=0.49)$. The links between the upwelling PC1 and SLP as well as the air temperature imply that other factors also affect upwelling.

Finally, we correlate the monsoon indices with the SLP field to gain a better understanding about their different influences on the upwelling. Same as the analysis of the correlation between upwelling and the monsoon indices, we extend the selected period
OSD

12, 2683-2704, 2015

The relationship between Arabian Sea upwelling and Indian monsoon revisited

X. Yi et al.

\section{Title Page}

Abstract Introduction

Conclusions References

Tables

Figures

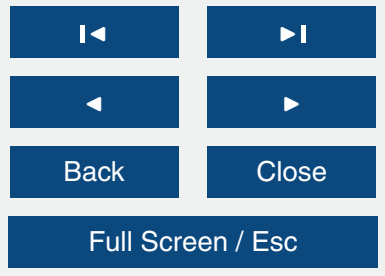

Printer-friendly Version

Interactive Discussion 
of SLP to JJAS before the calculation. The IMI (Fig. 6a) and IMR (Fig. 6b) again show similar patterns. They both have positive correlations with the SLP over the Tibetan Plateau and strong negative correlations in the Arabian Sea. Some minor differences are that the strong negatively correlated region with IMR is larger than that with IMI 5 and the IMI shows more positive correlated areas over North Africa. The positive correlations over the Tibetan Plateau and the negative correlations in the Arabian Sea explains the similar correlation patterns between these two monsoon indices and the upwelling velocity shown in Fig. 4. The WYM (Fig. 6c), however, does not present significant correlation gradient with the SLP over the Tibetan Plateau and in the Arabian

10 Sea. It reveals concentrated negative correlations along the coastal area and shares a similar positive correlation pattern over the North Africa as shown in IMI. Considering the significant correlation between the upwelling velocity and the SLP revealed in Fig. 5, it is possible to conclude that the upwelling is related to the monsoon, however the driving forces of the upwelling and the monsoon are different.

\section{$15 \quad 7$ Discussion and conclusions}

In this study we use the vertical water mass transport data provided by a high-resolution global ocean simulation over the past decades to identify the atmospheric drivers of upwelling along the west coast of the Arabian Sea. With significantly improved spatial resolution, our modeled upwelling velocity presents consistent annual cycle with the traditional upwelling indices.

One limitation of our study that has to be borne in mind is the degree of realism of the ocean model used. Another possible limitation is the realism of the atmospheric forcing (NCEP/NCAR meteorological reanalysis) used to drive the ocean model. It is difficult to validate the simulated upwelling against direct observations of vertical velocities, and thus we have to rely on indirect analysis. Here, we showed that the link between simulated upwelling and SSTs, and the correlation between simulated upwelling and
OSD

12, 2683-2704, 2015

The relationship between Arabian Sea upwelling and Indian monsoon revisited

X. Yi et al.

Title Page

Abstract Introduction

Conclusions References

Tables

Figures

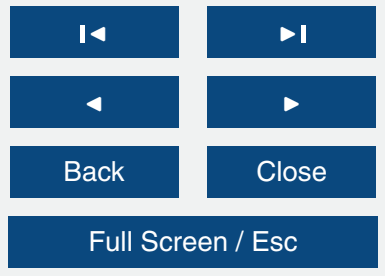

Printer-friendly Version

Interactive Discussion 
independent wind-stress data suggest a reasonable degree of realism of the ocean simulation.

One main conclusion of our study is that in general, no significant long-term trend is detected in the upwelling time series.

$5 \quad$ The upwelling intensity and variability are found to be higher along the southern coast than along the northern coast and this tendency is revealed in the upwelling variability as well. This result suggests that upwelling along the southern coast is more intense. In addition, the southern coast is also the region where upwelling is most significantly connected to the ISM but the correlation between them is not as high as expected

10 from previous studies. Therefore, this simulation does not reveal a strong impact of the Indian Monsoon on the western Arabian Sea coastal upwelling.

This low correlation points to other processes that might contribute to the upwelling variability. Both SLP and surface air temperature are considered and are compared with the upwelling PC1. The comparisons indicate that the upwelling is strongly af15 fected by the SLP gradient between the Himalayas and the Arabian Sea as well as the air temperature gradient between the Tibetan Plateau and northern India. These two gradients, however, also affect the ISM (Feng and Hu, 2005; Krishnamurthy and Ajayamohan, 2010) so caution should be taken when distinguishing the sources that influence the upwelling. On one hand, the upwelling is weakly correlated to the ISM but significantly correlated to the SLP and the air temperature gradients; on the other hand, both of the SLP and the air temperature gradients are associated with the ISM. Nevertheless, due to the significant correlation between this SLP gradient and the upwelling, it is possible to derive a new upwelling index based on this gradient to describe the western Arabian Sea coastal upwelling.

The lack of long-term observational data restricts the validation of the results and the data from satellite ocean-color observations are heavily blocked during the upwelling season in the Arabian Sea. Methods such as the one described by Banzon et al. (2004) will help to recover the gaps in the satellite data and thus the recovered data might be possible to further inspect the results in this study.
OSD

12, 2683-2704, 2015

The relationship between Arabian Sea upwelling and Indian monsoon revisited

X. Yi et al.

Title Page

Abstract Introduction

Conclusions References

Tables

Figures

14

$\rightarrow$ I

4

Back

Full Screen / Esc

Printer-friendly Version

Interactive Discussion 
Acknowledgements. This work is funded by the Cluster of Excellence Integrated Climate System Analysis and Prediction (CliSAP) Project B3. We thank the Max-Planck-Institute for Meteorology for providing the model data. All the other publicly available data used in this study are gratefully acknowledged.

5

The article processing charges for this open-access publication were covered by a Research Centre of the Helmholtz Association.

\section{References}

Anderson, D. M., Brock, J. C., and Prell, W. L.: Physical upwelling processes, upper ocean en10 vironment and the sediment record of the southwest monsoon, Geological Society, London, Special Publications, 64, 121-129, 1992.

Anderson, D. M., Overpeck, J. T., and Gupta, A. K.: Increase in the Asian southwest monsoon during the past four centuries, Science, 297, 596-599, 2002.

Atlas, R., Hoffman, R. N., Ardizzone, J., Leidner, S. M., Jusem, J. C., Smith, D. K., and Gombos, D.: A cross-calibrated multiplatform ocean surface wind velocity product for meteorological and oceanographic applications, B. Am. Meteorol. Soc., 92, 157-174, 2011.

Bakun, A.: Coastal Upwelling Indices, West Coast of North America, 1946-71, NOAA Tech. Rep., 1973, 103, US Department of Commerce, National Oceanic and Atmospheric Administration, National Marine Fisheries Service, 1973.

Bakun, A.: Global climate change and intensification of coastal ocean upwelling, Science, 247, 198-201, 1990.

Banzon, V. F., Evans, R. E., Gordon, H. R., and Chomko, R. M.: SeaWiFS observations of the Arabian Sea southwest monsoon bloom for the year 2000, Deep-Sea Res. Pt. II, 51, 189-208, 2004.

25 Brock, J. C. and Mcclain, C. R.: Interannual variability in phytoplankton blooms observed in the northwestern Arabian Sea during the Southwest Monsoon, J. Geophys. Res.-Oceans, 97, 733-750, 1992.

Brock, J. C., Mcclain, C. R., Luther, M. E., and Hay, W. W.: The phytoplankton bloom in the northwestern Arabian Sea during the Southwest Monsoon of 1979, J. Geophys. Res.-Oceans, 96,
OSD

12, 2683-2704, 2015

The relationship between Arabian Sea upwelling and Indian monsoon revisited

X. Yi et al.

Title Page

Abstract Introduction

Conclusions References

Tables Figures

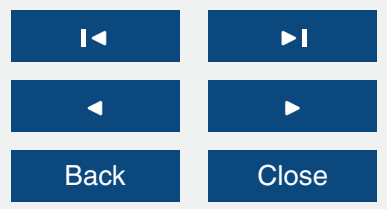

Full Screen / Esc

Printer-friendly Version

Interactive Discussion 
Casey, K. S., Brandon, T. B., Cornillon, P., and Evans, R.: The past, present, and future of the AVHRR Pathfinder SST program, in: Oceanography from Space, Springer Netherlands, Dordrecht, the Netherlands, 273-287, 2010.

Curry, W., Ostermann, D., Guptha, M., and Ittekkot, V.: Foraminiferal production and monsoonal upwelling in the Arabian Sea: evidence from sediment traps, Geological Society, London, Special Publications, 64, 93-106, 1992.

Emeis, K. C., Anderson, D. M., Doose, H., Kroon, D., and Schulzbull, D.: Sea-surface temperatures and the history of monsoon upwelling in the northwest Arabian Sea during the last 500,000 years, Quaternary Res., 43, 355-361, 1995.

10 Feng, S. and Hu, Q.: Regulation of Tibetan Plateau heating on variation of Indian summer monsoon in the last two millennia, Geophys. Res. Lett., 32, L02702, doi:10.1029/2004GL021246, 2005.

Findlater, J.: A major low-level air current near Indian Ocean during northern summer, Q. J. Roy. Meteor. Soc., 95, 362-380, 1969.

Godad, S. P., Naidu, P. D., and Malmgren, B. A.: Sea surface temperature changes during May and August in the western Arabian Sea over the last $22 \mathrm{kyr}$ : implications as to shifting of the upwelling season, Mar. Micropaleontol., 78, 25-29, 2011.

Izumo, T., Montegut, C. D., Luo, J. J., Behera, S. K., Masson, S., and Yamagata, T.: The role of the western Arabian Sea upwelling in Indian Monsoon rainfall variability, J. Climate, 21, 5603-5623, 2008.

Jacox, M. G., Moore, A. M., Edwards, C. A., and Fiechter, J.: Spatially resolved upwelling in the California Current System and its connections to climate variability, Geophys. Res. Lett., 41, 3189-3196, 2014.

Kalnay, E., Kanamitsu, M., Kistler, R., Collins, W., Deaven, D., Gandin, L., Iredell, M., Saha, S., White, G., Woollen, J., Zhu, Y., Chelliah, M., Ebisuzaki, W., Higgins, W., Janowiak, J., Mo, K. C., Ropelewski, C., Wang, J., Leetmaa, A., Reynolds, R., Jenne, R., and Joseph, D.: The NCEP/NCAR 40-year reanalysis project, B. Am. Meteorol. Soc., 77, 437-471, 1996.

Krishnamurthy, V. and Ajayamohan, R. S.: Composite structure of Monsoon low pressure systems and its relation to Indian rainfall, J. Climate, 23, 4285-4305, 2010.

30 Kroon, D., Steens, T., and Troelstra, S. R.: Onset of monsoonal related upwelling in the western Arabian Sea as revealed by planktonic foraminifers, Proceedings of the Ocean Drilling Program, Scientific Results, 117, 257-263, 1991.
OSD

12, 2683-2704, 2015

The relationship between Arabian Sea upwelling and Indian monsoon revisited

X. Yi et al.

Title Page

Abstract Introduction

Conclusions References

Tables

Figures

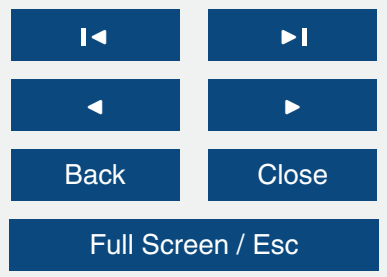

Printer-friendly Version

Interactive Discussion 
Ma, J. F., Liu, H. L., Lin, P. F., and Zhan, H. G.: Seasonality of biological feedbacks on sea surface temperature variations in the Arabian Sea: the role of mixing and upwelling, J. Geophys. Res.-Oceans, 119, 7592-7604, 2014.

Manghnani, V., Morrison, J. M., Hopkins, T. S., and Bohm, E.: Advection of upwelled waters 5 in the form of plumes off Oman during the Southwest Monsoon, Deep-Sea Res. Pt. II, 45, 2027-2052, 1998.

Naik, S. S., Godad, S. P., Naidu, P. D., and Ramaswamy, V.: A comparison of Globigerinoides ruber calcification between upwelling and non-upwelling regions in the Arabian Sea, J. Earth Syst. Sci., 122, 1153-1159, 2013.

10 Narayan, N., Paul, A., Mulitza, S., and Schulz, M.: Trends in coastal upwelling intensity during the late 20th century, Ocean Sci., 6, 815-823, doi:10.5194/os-6-815-2010, 2010.

Parthasarathy, B., Munot, A. A., and Kothawale, D. R.: All-India monthly and seasonal rainfall series - 1871-1993, Theor. Appl. Climatol., 49, 217-224, 1994.

Prell, W. L. and Curry, W. B.: Faunal and isotopic indexes of monsoonal upwelling - western 15 Arabian Sea, Oceanol. Acta, 4, 91-98, 1981.

Prell, W. L. and Vancampo, E.: Coherent response of Arabian Sea upwelling and pollen transport to Late Quaternary Monsoonal winds, Nature, 323, 526-528, 1986.

Rao, A. D., Joshi, M., and Ravichandran, M.: Oceanic upwelling and downwelling processes in waters off the west coast of India, Ocean Dynam., 58, 213-226, 2008.

20 Rixen, T., Haake, B., and Ittekkot, V.: Sedimentation in the western Arabian Sea the role of coastal and open-ocean upwelling, Deep-Sea Res. Pt. II, 47, 2155-2178, 2000.

Shi, W., Morrison, J. M., Bohm, E., and Manghnani, V.: The Oman upwelling zone during 1993, 1994 and 1995, Deep-Sea Res. Pt. II, 47, 1227-1247, 2000.

Tozuka, T., Nagura, M., and Yamagata, T.: Influence of the reflected Rossby waves on the 25 western Arabian Sea upwelling region, J. Phys. Oceanogr., 44, 1424-1438, 2014.

von Storch, H. and Zwiers, F. W.: Statistical Analysis in Climatic Research, Cambridge University Press, Cambridge, UK, 484 pp., 2001.

von Storch, J.-S., Eden, C., Fast, I., Haak, H., Hernández-Deckers, D., Maier-Reimer, E., Marotzke, J., and Stammer, D.: An estimate of the Lorenz energy cycle for the world ocean

30 based on the STORM/NCEP simulation, J. Phys. Oceanogr., 42, 2185-2205, 2012.

Wang, B. and Fan, Z.: Choice of south Asian summer monsoon indices, B. Am. Meteorol. Soc., 80, 629-638, 1999.

\section{OSD}

12, 2683-2704, 2015

\section{The relationship between Arabian Sea upwelling and Indian monsoon revisited}

X. Yi et al.

\section{Title Page}

Abstract

Introduction

Conclusions References

Tables

Figures

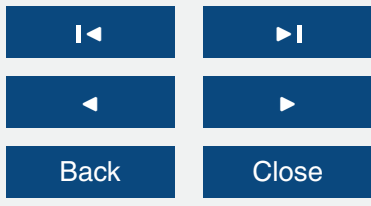

Full Screen / Esc

Printer-friendly Version

Interactive Discussion 
Wang, D. W., Gouhier, T. C., Menge, B. A., and Ganguly, A. R.: Intensification and spatial homogenization of coastal upwelling under climate change, Nature, 518, 390-394, 2015.

Webster, P. J. and Yang, S.: Monsoon and Enso - selectively interactive systems, Q. J. Roy. Meteor. Soc., 118, 877-926, 1992.

5 Willmott, C. and Matsuura, K.: Terrestrial Air Temperature: 1900-2010 Gridded Monthly Time Series, Version 3.01, Center for Climatic Research, Dep. of Geography, University of Delaware, Newark, available at: http://climate.geog.udel.edu/ climate (last access: 1 September 2014), 2012.

Yelland, M. and Taylor, P. K.: Wind-stress measurements from the open ocean, J. Phys. Oceanogr., 26, 541-558, 1996.

OSD

12, 2683-2704, 2015

\section{The relationship between Arabian Sea upwelling and Indian monsoon revisited}

X. Yi et al.

\section{Title Page}

Abstract

Introduction

Conclusions

References

Tables

Figures

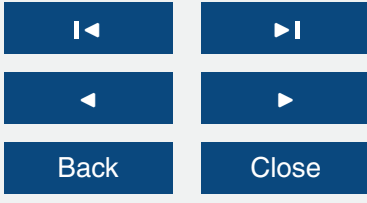

Full Screen / Esc

Printer-friendly Version

Interactive Discussion 

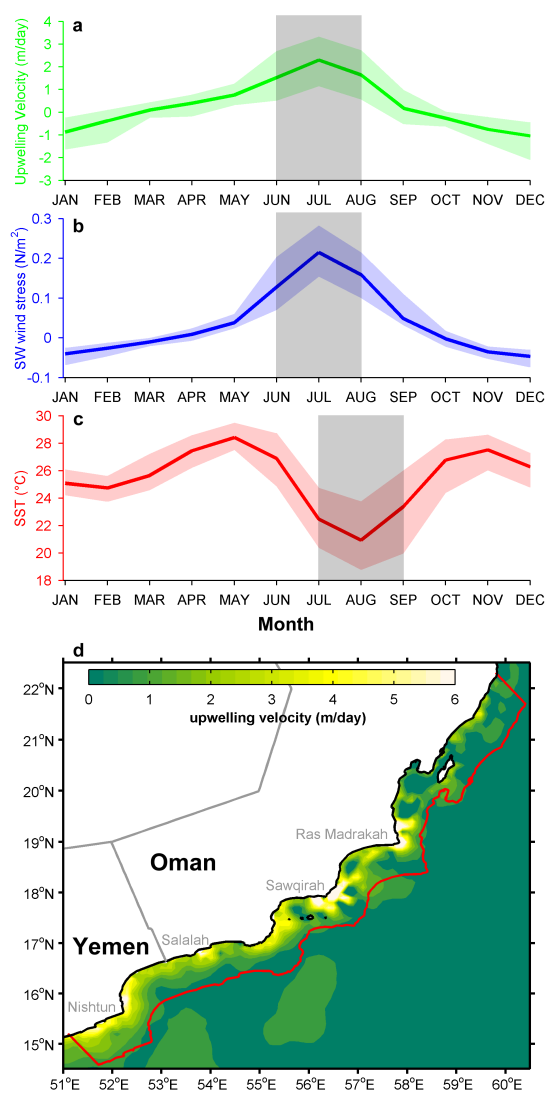

OSD

12, 2683-2704, 2015

The relationship between Arabian Sea upwelling and Indian monsoon revisited

X. Yi et al.

Title Page

Figure 1. Annual cycle of (a) upwelling velocity, (b) SW wind-stress and (c) sea-surface temperature averaged for the study area. Color shaded areas are the ranges of the annual cycles and grey shaded months are the study periods selected for each variable. (d) JJA mean upwelling velocity from 1950 to 2010 . The red contour demonstrates the study area.

Back

Close

Full Screen / Esc

Printer-friendly Version

Interactive Discussion 

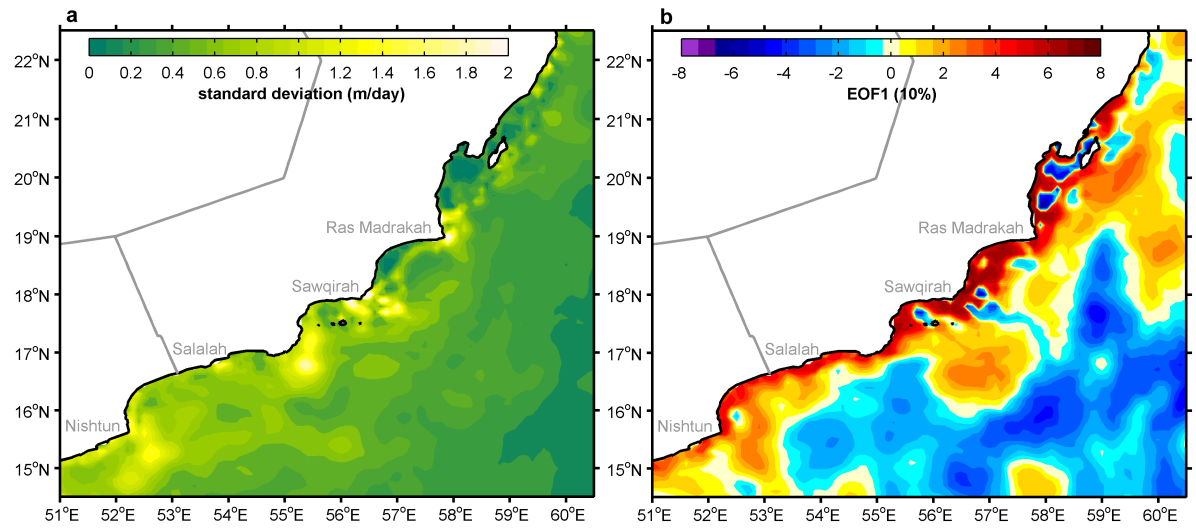

Figure 2. (a) Standard deviation of JJA upwelling velocity from 1950 to 2010. (b) First mode of the EOF analysis with its explained variance in parentheses.

OSD

12, 2683-2704, 2015

The relationship between Arabian Sea upwelling and Indian monsoon revisited

X. Yi et al.

Title Page

Abstract

Introduction

Conclusions

References

Tables

Figures

14

4

Back

Close

Full Screen / Esc

Printer-friendly Version

Interactive Discussion 


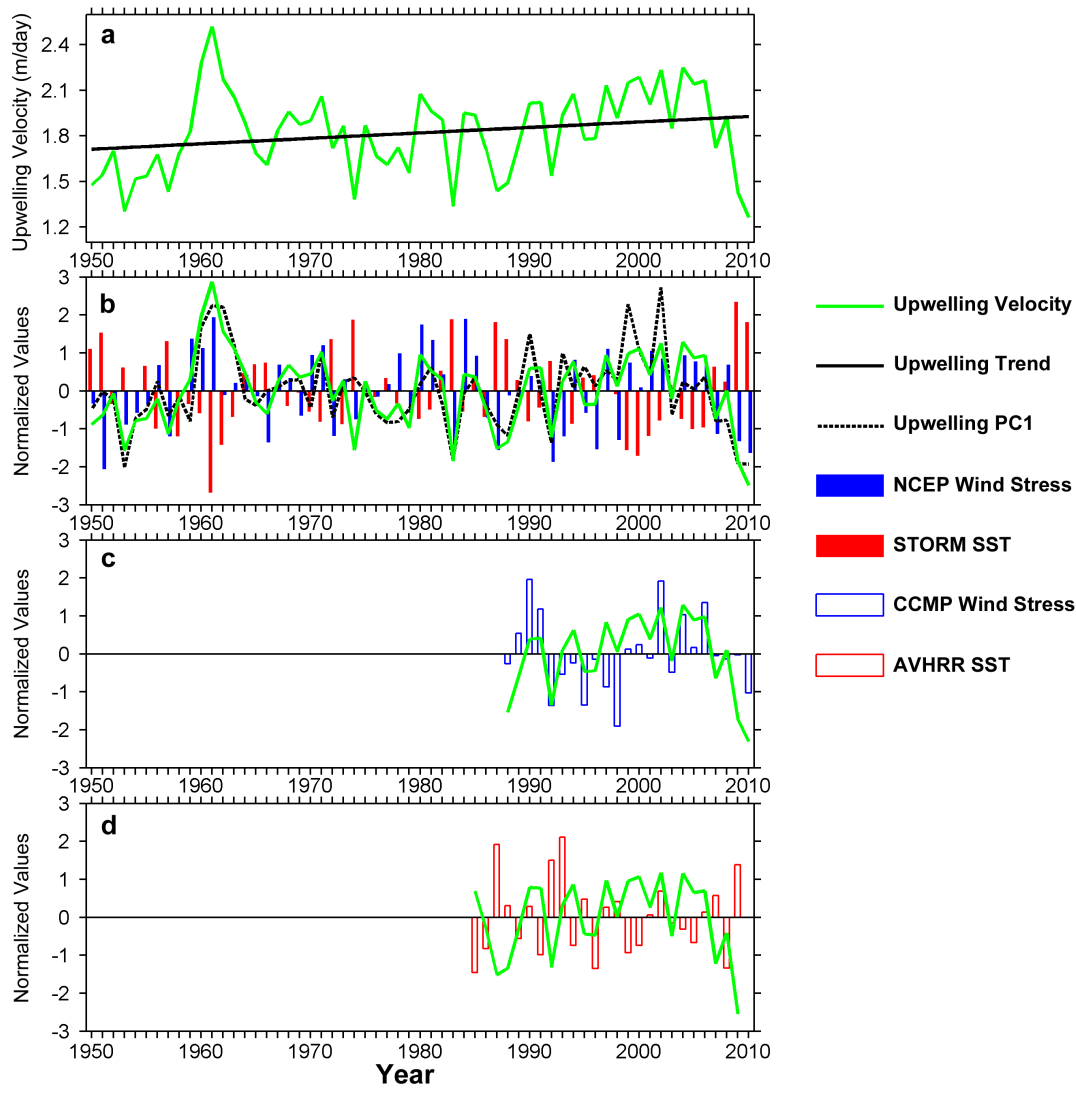

OSD

12, 2683-2704, 2015

The relationship between Arabian Sea upwelling and Indian monsoon revisited

X. Yi et al.

Title Page

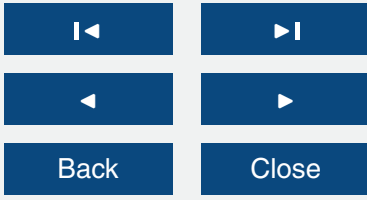

Full Screen / Esc

Figure 3. (a) Time series of upwelling velocity and its long term trend. (b) Comparison of upwelling velocity, upwelling PC1, SW wind-stress from NCEP and SST from STORM. (c) Upwelling velocity and SW wind-stress from CCMP. (d) Upwelling velocity and SST from AVHRR. All the time series in (b), (c) and (d) are detrended and normalized.

Printer-friendly Version

Interactive Discussion

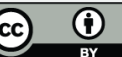




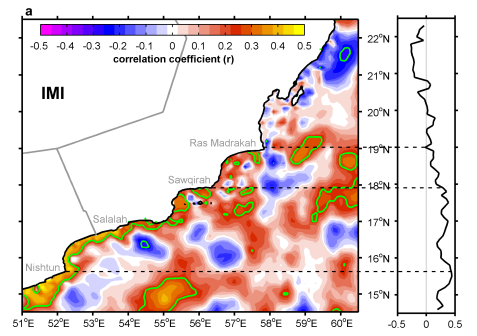

OSD

12, 2683-2704, 2015
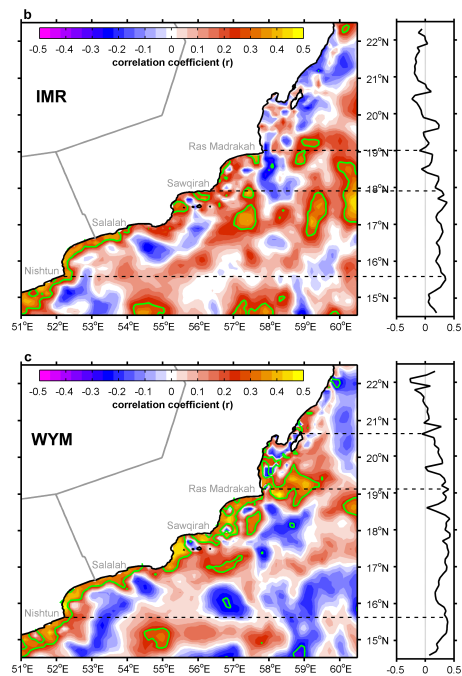

\section{The relationship between Arabian Sea upwelling and Indian monsoon revisited}

X. Yi et al.

Title Page

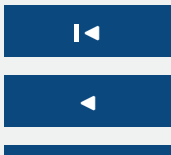

$\Delta$

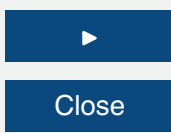

Full Screen / Esc

Figure 4. Correlation between upwelling velocity and (a) IMI, (b) IMR as well as (c) WYM indices. Within the green contours are the areas where the significant levels are $95 \%$ or higher. The plots on the right column are the meridional mean correlation coefficient between upwelling velocity and each monsoon index averaged within the study area. The upper dashed line indicates the general starting points of the positive correlation. Between the middle and the lower dashed lines are the areas where the correlations are the highest.

Printer-friendly Version

Interactive Discussion

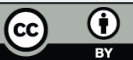



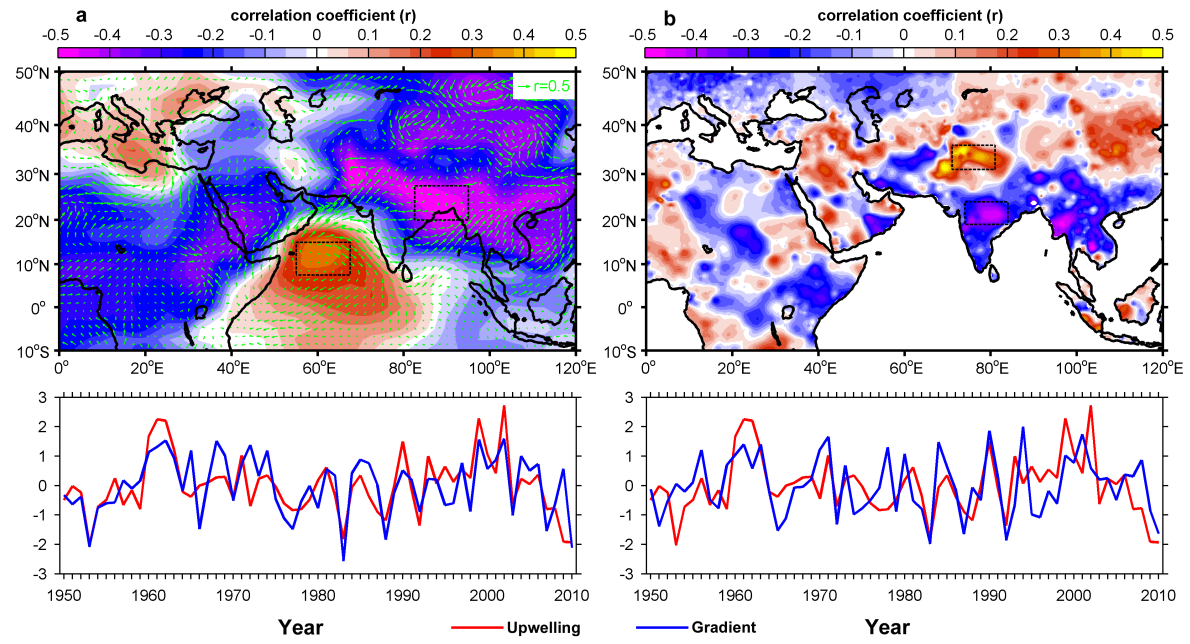

Figure 5. (a) Correlation between upwelling PC1 and SLP is represented by the background color contour. Green arrows are the two-dimensional correlation between upwelling velocity and the wind speed. (b) Background color contour is the correlation between upwelling PC1 and the air temperature. The lower plots are the time series of the PC1 and the corresponding time series of the gradient between the two selected boxes in the upper maps. The two plots are detrended and normalized.

OSD

12, 2683-2704, 2015

\section{The relationship between Arabian Sea upwelling and Indian monsoon revisited}

X. Yi et al.

\section{Title Page}

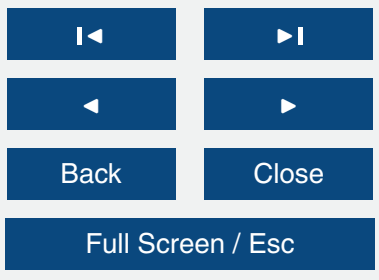

Printer-friendly Version

Interactive Discussion 

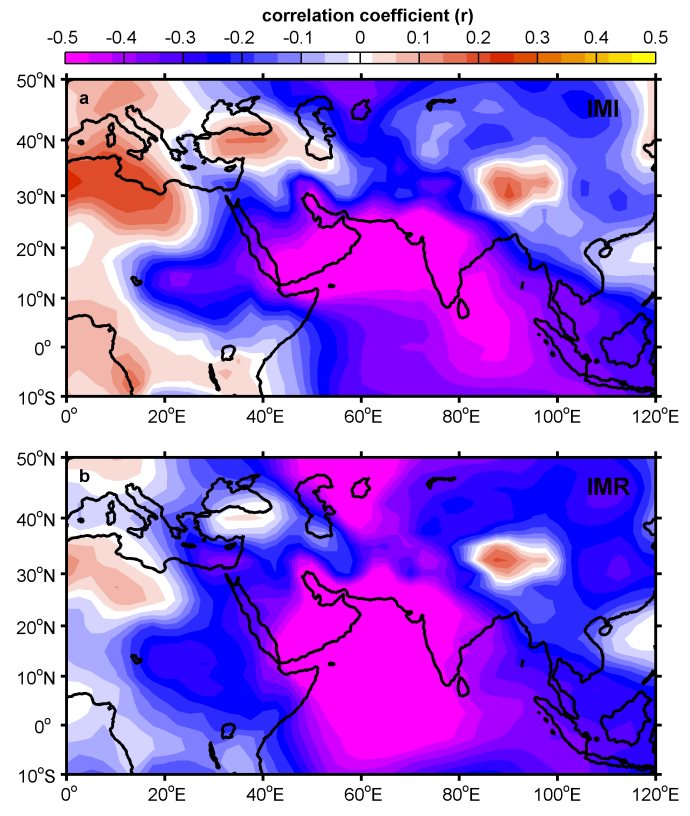

\section{OSD}

12, 2683-2704, 2015

\section{The relationship between Arabian Sea upwelling and Indian monsoon revisited}

X. Yi et al.

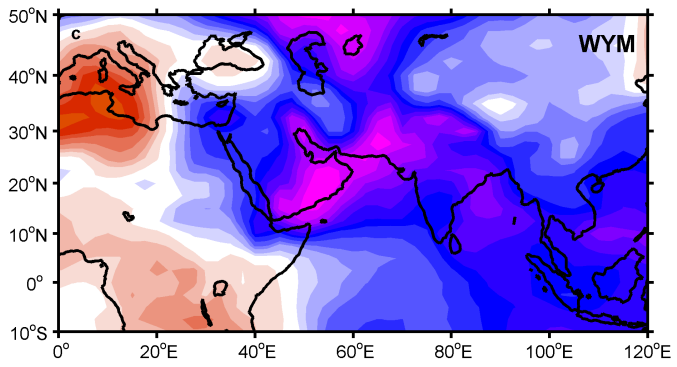

Title Page

Abstract

Introduction

Conclusions

References

Tables

Figures

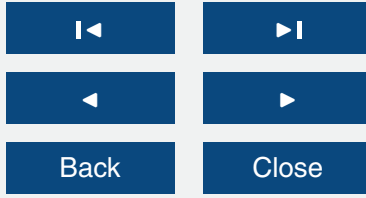

Full Screen / Esc

Printer-friendly Version

Interactive Discussion

Figure 6. Correlations between SLP and the monsoon indices: (a) IMI, (b) IMR and (c) WYM. 